ISSN 1392-3196 / e-ISSN 2335-8947

Zemdirbyste-Agriculture, vol. 104, No. 1 (2017), p. 79-84

DOI 10.13080/z-a.2017.104.011

\title{
Effect of potassium bicarbonate on photosynthetic parameters of Setaria viridis under drought conditions
}

\author{
Natalija BURBULIS, Rimanta VAINORIENĖ, Aušra BLINSTRUBIENE, Vaida JONYTIENÉ, \\ Vytautas LIAKAS
}

Aleksandras Stulginskis University

Studentų 11, Akademija, Kaunas distr., Lithuania

E-mail: natalija.burbulis@asu.lt

\begin{abstract}
The current study set out to investigate the effects of drought stress and potassium bicarbonate $\left(\mathrm{KHCO}_{3}\right)$ on green foxtail (Setaria viridis (L.) Beauv.) photosystem II (PSII) photochemistry under a moderate and severe drought. The plants at phenological stage 13 (according to $\mathrm{BBCH}$ scale) were divided into three groups and sprayed with water or with 10, 20 and $30 \mathrm{mg} \mathrm{l}^{-1} \mathrm{KHCO}_{3}$. The plants of the first group (well-watered) were hand-watered every second day. The plants of the second (moderately stressed) and third (severely stressed) groups were used for drought stress treatment by withholding water. The results indicated that drought conditions resulted in a decrease in maximum quantum yield and effective quantum yield most likely due to the expected photoinhibition of photosystem II. Decreased gas exchange parameters revealed that the reduction in photosynthesis of green foxtail under drought stress was caused by the stomatal factors. A significant increase in the maximum quantum yield, effective quantum yield and gas exchange parameters in $\mathrm{KHCO}_{3}$ treated plants showed that $\mathrm{KHCO}_{3}$ protects photosystem II of green foxtail from drought, and may have potential benefit for other $\mathrm{C}_{4}$ plants.
\end{abstract}

Key words: drought stress, green foxtail, $\mathrm{KHCO}_{3}$, photosystem II.

\section{Introduction}

Among different abiotic stresses, such as low and high temperature, salinity, pollutants, etc., drought is considered as a major abiotic factor that limits plant growth and development (Reddy et al., 2004). Earl and Davis (2003) have suggested that three main mechanisms decrease crop yield under drought stress: reduced absorption of photosynthetically active radiation, decreased radiation-use efficiency and reduced harvest index. Drought-induced stomatal limitation is generally accepted as the main factor which determines reduction in photosynthesis (Farooq et al., 2009). Moreover, restricted availability of carbon dioxide resulted in increased sensitivity to photo-damage (Reddy et al., 2004; Pinheiro, Chaves, 2011). Besides, inhibition of $\mathrm{CO}_{2}$ assimilation results in accelerated production of active oxygen via the chloroplast Mehler reaction because of the excessive light energy that cannot be converted to biochemical energy (Foyer, Noctor, 2005).

Ghannoum (2009) assumed that $\mathrm{C}_{4}$ plants make a significant contribution to the global carbon budget, and $\mathrm{C}_{4}$ crops, including maize, sugarcane, sorghum, millets, giant miscanthus and switchgrass, are determinant to current and future food security around the world. Setaria viridis (L.) Beauv. (green foxtail) is a member of the Panicoideae subfamily and is a close relative of several major forage and bioenergy grasses. Due to its $\mathrm{C}_{4}$ carbon fixation pathway, diploid nature, short life cycle and relatively small genome $(\sim 510 \mathrm{Mb})$, green foxtail has been rapidly adopted as a model for investigations the genetic of the biofuel crop switchgrass and for $\mathrm{C}_{4}$ photosynthesis (Doust et al., 2009; Brutnell et al., 2010; Li, Brutnell, 2011; Layton, Kellogg, 2014). Ghannoum (2009) has indicated that $\mathrm{C}_{4}$ plants may by similarly or even more sensitive in comparison with $\mathrm{C}_{3}$ plants but the response of $\mathrm{C}_{4}$ plants to drought stress has not been so well studied as response of $\mathrm{C}_{3}$ plants and it is important to understand how drought stress influences the photosynthesis in $\mathrm{C}_{4}$ plants.

Potassium is one of the essential macro elements in plant nutrition and energy metabolism such as accumulation of carbohydrates, photosynthesis, and maintenance of normal water regime (Wang et al., 2013). In plant cells, potassium is found in various salts, including potassium bicarbonate $\left(\mathrm{KHCO}_{3}\right)$. Because $\mathrm{KHCO}_{3}$ is harmless for the environment, it can be used in ecological farms (European Commission, 2014). It has been reported that $\mathrm{KHCO}_{3}$ can be used to reduce plant stress under low amounts of $\mathrm{CO}_{2}(\mathrm{Li}, \mathrm{Hao}, 2013)$, as an effective fungicide against mildew (Wenneker, Kanne, 2010) and apple scab (Marku et al., 2014). It was shown that spraying with 
$\mathrm{KHCO}_{3}$ resulted in increased photosynthesis in rice and soybean (Yao et al., 2009; Li, Hao, 2013). However, no information is available in the literature on the influence of potassium bicarbonate on the photosynthesis in $\mathrm{C}_{4}$ plants. Therefore, the aim of this study is to evaluate the effect of potassium bicarbonate $\left(\mathrm{KHCO}_{3}\right)$ on photosystem II (PSII) photochemistry in green foxtail (as a model $\mathrm{C}_{4}$ plant) under drought conditions.

\section{Materials and methods}

Research was carried out in Institute of Biology and Plant Biotechnology of Aleksandras Stulginskis University and Laboratory of Agrobiotechnology of Joint Research Centre in 2015.

Plant cultivation and drought treatment. The plants of green foxtail (Setaria viridis (L.) Beauv.) were grown in plastic pots $12 \mathrm{~cm}$ in diameter and $10 \mathrm{~cm}$ in height, 50 plants per pot, in a growth chamber MLR351 (Sanyo Electric Co., Ltd). The pots were filled with substrate which was composed of peat and sand at 3:1 volume ratio. Environmental conditions in the growth chamber were as follows: light intensity $-150 \mu \mathrm{mol}$ $\mathrm{m}^{-2} \mathrm{~s}^{-1}$, photoperiod $-16 / 8 \mathrm{~h}$ (day/night), temperature $-25 / 18^{\circ} \mathrm{C}$, relative air humidity $-65 \pm 5 \%$. The plants were hand-watered every second day to maintain $65 \pm$ 5\% substrate humidity. After four weeks, the plants (at phenological stage 13 according to $\mathrm{BBCH}$ scale) were divided into three groups and sprayed with water or with 10, 20 and $30 \mathrm{mg} \mathrm{l}^{-1}$ potassium bicarbonate $\left(\mathrm{KHCO}_{3}\right)$. The plants of the first group (well-watered) were handwatered every second day. The plants of the second (moderately stressed) and third (severely stressed) groups were used for drought stress treatment by withholding water. Substrate water content (SWC) was determined by taking daily samples with a cylindrical borer $(1.4 \mathrm{~cm}$ diameter and $10 \mathrm{~cm}$ length) and gravimetrically measuring by weighting the samples shortly after sampling and after drying them to a constant weight. Substrate water content (\%) was calculated as SWC = wet weight - dry weight / wet weight $\times 100$. Experiments were set up in a complete randomized design with three replicates per treatment and 150 plants per each replicate. At the end of experiment, when substrate humidity was $65 \pm 5 \%$ for well-watered, $45 \pm 5 \%$ for moderately stressed and $25 \pm$ $5 \%$ for severely stressed plants, chlorophyll fluorescence and gas exchange parameters were measured.

Measurement of chlorophyll fluorescence. Chlorophyll fluorescence was measured at room temperature in dark-adapted for 20 minutes green foxtail leaves with a portable fluorometer IMAGING-PAM M-Series (Walz, Germany). The experimental protocol of Genty et al. (1989) was followed. The minimal $\left(\mathrm{F}_{0}\right)$ and maximal $\left(\mathrm{F}_{\mathrm{m}}\right)$ fluorescence levels were measured in the middle region of the second pair of fully expanded leaves after 20 minutes dark adaptation. All measurements were performed on 3 plants of each replication. Maximum quantum yield $\left(\mathrm{F}_{\mathrm{v}} / \mathrm{F}_{\mathrm{m}}\right)$ of effective quantum yield $\left(\Phi_{\mathrm{PSII}}\right)$ of PSII photochemistry and non-photochemical quenching (NPQ) were calculated according to the following equations: $\mathrm{F}_{\mathrm{v}} / \mathrm{F}_{\mathrm{m}}=\left(\mathrm{F}_{\mathrm{m}}-\mathrm{F}_{0}\right) / \mathrm{F}_{\mathrm{m}}, \Phi_{\mathrm{PSII}}=\left(\mathrm{F}_{\mathrm{m}},-\mathrm{F}_{\mathrm{s}}\right) / \mathrm{F}_{\mathrm{m}}$ and $\mathrm{NPQ}=\left(\mathrm{F}_{\mathrm{m}}-\mathrm{F}_{\mathrm{m}}\right) / \mathrm{F}_{\mathrm{m}}$, (Genty et al., 1989).
Measurement of gas exchange. Gas exchange was measured with a portable fluorescence system GFC-3000 (Walz, Germany). Stomatal conductance $\left(\mathrm{g}_{\mathrm{s}}\right)$ $\left(\mathrm{mmol} \mathrm{H}_{2} \mathrm{O} \mathrm{m}^{-2} \mathrm{~s}^{-1}\right)$, transpiration rate $(\mathrm{E})\left(\mathrm{mmol} \mathrm{H}_{2} \mathrm{O}\right.$ $\left.\mathrm{m}^{-2} \mathrm{~s}^{-1}\right)$ and net photosynthetic rate $\left(\mathrm{P}_{\mathrm{N}}\right)\left(\mu \mathrm{mol} \mathrm{m} \mathrm{m}^{-2} \mathrm{~s}^{-1}\right)$ of a second pair of fully expanded leaves were registered every 30 seconds for 40 minutes; from these data there were calculated. All measurements were performed on 3 plants of each replication. Environmental conditions during the experiments were as follows: air flow rate $400 \mu \mathrm{mol} \mathrm{s} \mathrm{s}^{-1}$, block and leaf temperature $-25^{\circ} \mathrm{C}, \mathrm{CO}_{2}$ concentration in a sample cell - 300-400 $\mu \mathrm{mol} \mathrm{CO}_{2} \mathrm{~mol}^{-}$ ${ }^{1}$, relative humidity in a sample cell $-30 \%$ and lightness in quant $-180 \mu \mathrm{mol} \mathrm{m} \mathrm{m}^{-2} \mathrm{~s}^{-1}$.

Statistical analysis. The least significant differences of the results were calculated using the software STAT 1.55 from SELEKCIJA and IRRISTAT (Tarakanovas, Raudonius, 2003). The mean value and standard error (SE) for each treatment were calculated based on the number of independent replications.

\section{Results and discussion}

The effect of $\mathrm{KHCO}_{3}$ on the stability of PSII under drought stress was investigated. The responses of the maximum quantum yield $\left(\mathrm{F}_{\mathrm{v}} / \mathrm{F}_{\mathrm{m}}\right)$ of PSII photochemistry to $\mathrm{KHCO}_{3}$ treatment are shown in Figure 1. Decreased $\mathrm{F}_{\mathrm{v}} / \mathrm{F}_{\mathrm{m}}$ under drought stress indicates damage to the PSII reaction centre (Nar etal., 2009; Oukarroum et al., 2012). In this study, the decrease of the $F_{v} / F_{m}$ in the $\mathrm{KHCO}_{3}$ untreated plants under drought stress was more pronounced in comparison with $\mathrm{KHCO}_{3}$ treated plants. Under $\mathrm{KHCO}_{3}$ treatment, $\mathrm{F}_{\mathrm{v}} / \mathrm{F}_{\mathrm{m}}$ value was $1.1-1.3$-fold higher (in moderately stressed plants) and 1.1-1.2-fold higher (in severely stressed plants) as compared to $\mathrm{KHCO}_{3}$ untreated plants. Lower decrease in $\mathrm{F}_{\mathrm{v}} / \mathrm{F}_{\mathrm{m}}$ values in $\mathrm{KHCO}_{3}$ treated plants indicates that $\mathrm{KHCO}_{3}$ might have a protective role in PSII under drought stress.

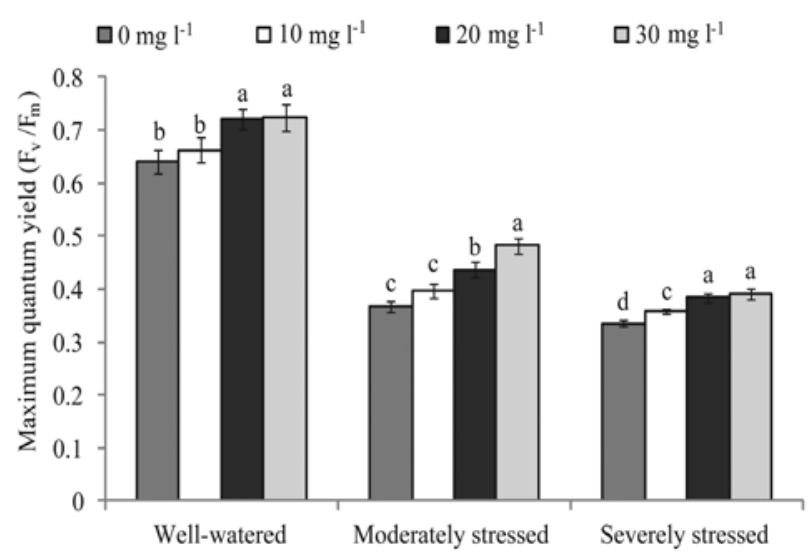

Note. Means not sharing a common letter $(\mathrm{a}, \mathrm{b})$ are significantly different $(P<0.05)$.

Figure 1. Effect of potassium bicarbonate $\left(\mathrm{KHCO}_{3}\right)$ on the maximum quantum yield $\left(\mathrm{F}_{\mathrm{v}} / \mathrm{F}_{\mathrm{m}}\right)$ of green foxtail plants under different ( $65 \pm 5 \%$ for well-watered, $45 \pm$ $5 \%$ for moderately stressed and $25 \pm 5 \%$ for severely stressed plants) substrate humidity 
Decrease of effective quantum yield $\left(\Phi_{\mathrm{PSII}}\right)$ of PSII photochemistry is related to down-regulation of electron transport and increase in excitation energy quenching in the PSII antennae (Ghannoum, 2009; Saglam et al., 2014). The $\Phi_{\text {PSII }}$ of the $\mathrm{KHCO}_{3}$ untreated plants under drought stress was decreased by 0.107 in moderately stressed plants and by 0.224 in severely stressed plants in comparison with well-watered plants (Fig. 2).

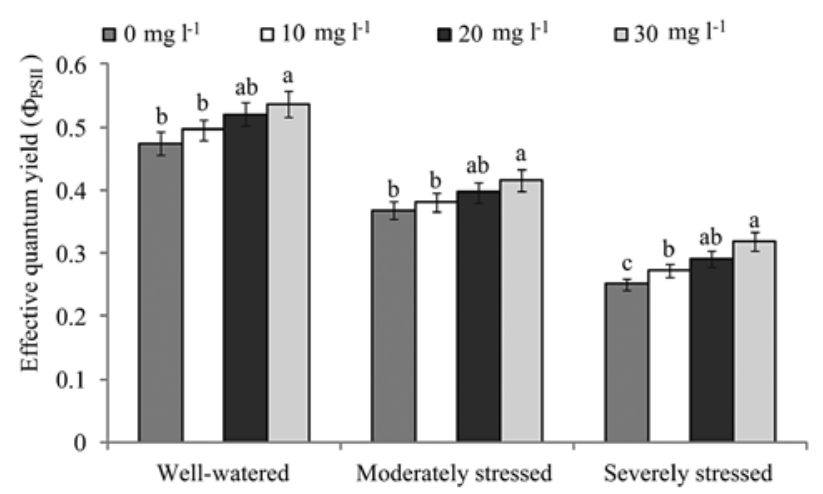

Note. Means not sharing a common letter $(\mathrm{a}, \mathrm{b})$ are significantly different $(P<0.05)$.

Figure 2. Effect of potassium bicarbonate $\left(\mathrm{KHCO}_{3}\right)$ on the effective quantum yield $\left(\Phi_{\mathrm{PSII}}\right)$ of green foxtail plants under different $(65 \pm 5 \%$ for well-watered, $45 \pm 5 \%$ for moderately stressed and $25 \pm 5 \%$ for severely stressed plants) substrate humidity

Under drought conditions, $\Phi_{\mathrm{PSII}}$ of the green foxtail treated with 20 and $30 \mathrm{mg} \mathrm{l}^{-1} \mathrm{KHCO}_{3}$ increased significantly in comparison with $\mathrm{KHCO}_{3}$ untreated plants. The obtained changes in the $\Phi_{\text {PSII }}$ parameter also supported the protective role of $\mathrm{KHCO}_{3}$ in the photosynthetic system of green foxtail under drought stress.

Increase in non-photochemical quenching (NPQ) resulting from drought stress has been previously reported by several research groups (de Souza et al., 2013; Huang et al., 2013). The NPQ of $\mathrm{KHCO}_{3}$ untreated plants under drought stress was increased by 0.033 in moderately stressed plants and by 0.05 in severely stressed plants in comparison with well-watered plants (Fig. 3). NPQ of the well-watered green foxtail plants was not affected by the $\mathrm{KHCO}_{3}$ treatment, while under drought stress a statistically significant increase of NPQ in comparison with the $\mathrm{KHCO}_{3}$ untreated plants was obtained under 20 and $30 \mathrm{mg} \mathrm{l}^{-1} \mathrm{KHCO}_{3}$ treatment. In the present study, NPQ increase under the highest $\mathrm{KHCO}_{3}$ treatment indicated the thermal dissipation of energy load on the leaves, perhaps preventing photo damage. The increases in NPQ in foxtail leaves under $\mathrm{KHCO}_{3}$ indicated thermal dissipation of excess energy in our study and protective role of $\mathrm{KHCO}_{3}$ in the photosynthetic system.

Drought stressusually resulted in stomatal closure which resulted in decreased $\mathrm{CO}_{2}$ fixation (Chaves et al., 2009). Photosynthesis inhibition can disturb the balance between reactive oxygen species (ROS) and antioxidant production, which can result in ROS accumulation. At high concentration ROS become very injurious to

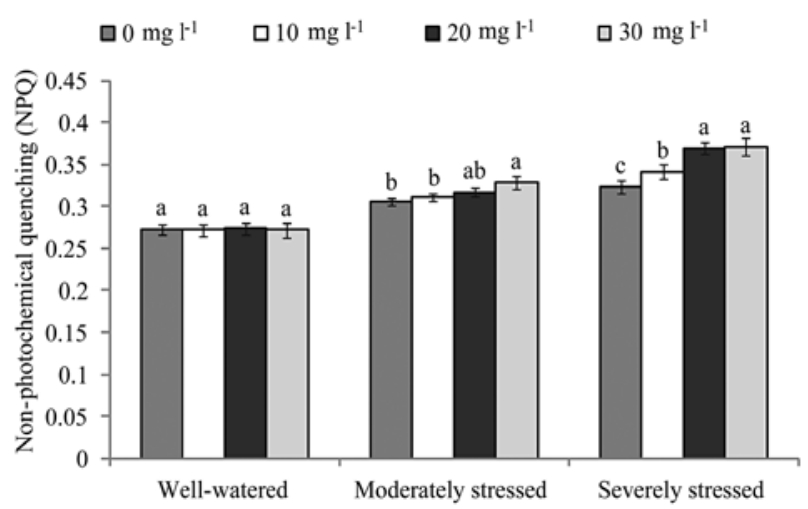

Note. Means not sharing a common letter $(\mathrm{a}, \mathrm{b})$ are significantly different $(P<0.05)$.

Figure 3. Effect of potassium bicarbonate $\left(\mathrm{KHCO}_{3}\right)$ on the non-photochemical quenching (NPQ) of green foxtail plants under different ( $65 \pm 5 \%$ for well-watered, $45 \pm$ $5 \%$ for moderately stressed and $25 \pm 5 \%$ for severely stressed plants) substrate humidity

various cell components (Farooq et al., 2009). It has been reported that drought stress can decrease potassium content in the chloroplast which may result in inhibited of photosynthesis and induce further ROS formation (Cakmak, 2005). Under drought conditions, the values of stomatal conductance $\left(\mathrm{g}_{\mathrm{s}}\right)$ of $\mathrm{KHCO}_{3}$ untreated green foxtail plants in the present study decreased by 73.9 mmol m-2 $\mathrm{s}^{-1}$ in moderately stressed plants and by 172.3 mmol m $\mathrm{m}^{-2} \mathrm{~s}^{-1}$ in severely stressed plants in comparison with well-watered plants (Fig. 4).

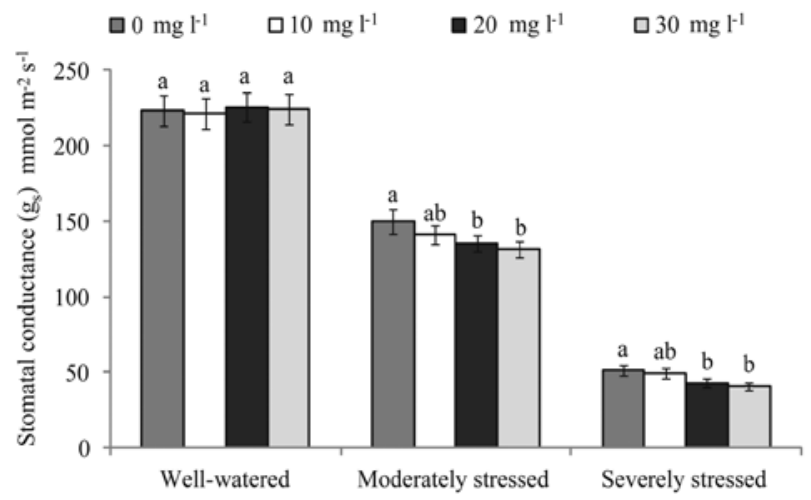

Note. Means not sharing a common letter $(\mathrm{a}, \mathrm{b})$ are significantly different $(P<0.05)$.

Figure 4. Effect of potassium bicarbonate $\left(\mathrm{KHCO}_{3}\right)$ on the stomatal conductance $\left(\mathrm{g}_{\mathrm{s}}\right)$ of green foxtail plants under different $(65 \pm 5 \%$ for well-watered, $45 \pm 5 \%$ for moderately stressed and $25 \pm 5 \%$ for severely stressed plants) substrate humidity

As a result, the transpiration rate (E) also decreased (Fig. 5). Stomatal conductance $\left(\mathrm{g}_{\mathrm{s}}\right)$ and transpiration rate $(\mathrm{E})$ of the well-watered green foxtail plants were not affected by the $\mathrm{KHCO}_{3}$ treatment, while under drought stress a statistically significant decrease of both parameters in comparison with the $\mathrm{KHCO}_{3}$ untreated plants was obtained under 20 and $30 \mathrm{mg}^{-1}$ $\mathrm{KHCO}_{3}$ treatment (Figs. 4 and 5). 


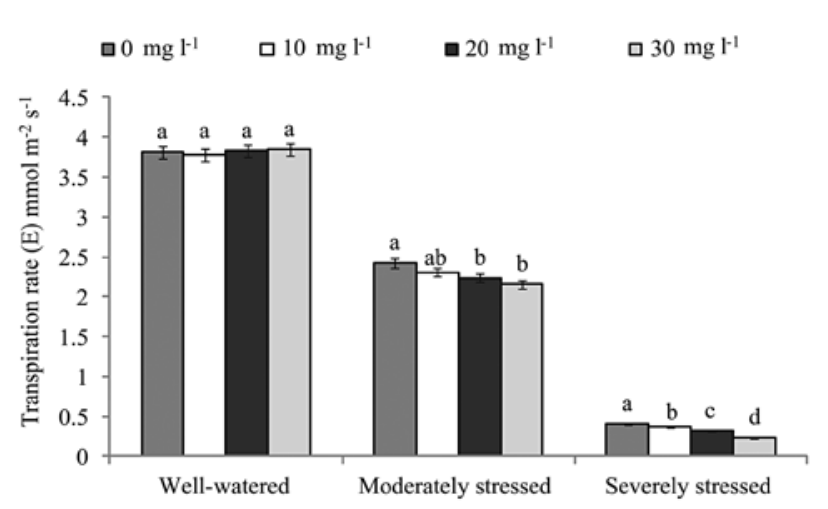

Note. Means not sharing a common letter $(\mathrm{a}, \mathrm{b})$ are significantly different $(P<0.05)$.

Figure 5. Effect of potassium bicarbonate $\left(\mathrm{KHCO}_{3}\right)$ on the transpiration rate $(\mathrm{E})$ of green foxtail plants under different $(65 \pm 5 \%$ for well-watered, $45 \pm 5 \%$ for moderately stressed and $25 \pm 5 \%$ for severely stressed plants) substrate humidity

Net photosynthetic rate $\left(\mathrm{P}_{\mathrm{N}}\right)$ of green foxtail plants was considerably affected by drought stress (Fig. 6). Under drought conditions, $\mathrm{P}_{\mathrm{N}}$ values of $\mathrm{KHCO}_{3}$ untreated plants decreased by $5.3 \mu \mathrm{mol} \mathrm{m} \mathrm{m}^{-2} \mathrm{~s}^{-1}$ in moderately stressed plants and by $11.5 \mu \mathrm{mol} \mathrm{m} \mathrm{m}^{-2} \mathrm{~s}^{-1}$ in severely stressed plants in comparison with well-watered plants. The decrease of $\mathrm{P}_{\mathrm{N}}$ in $\mathrm{KHCO}_{3}$ treated plants was significantly lower as compared with untreated plants.

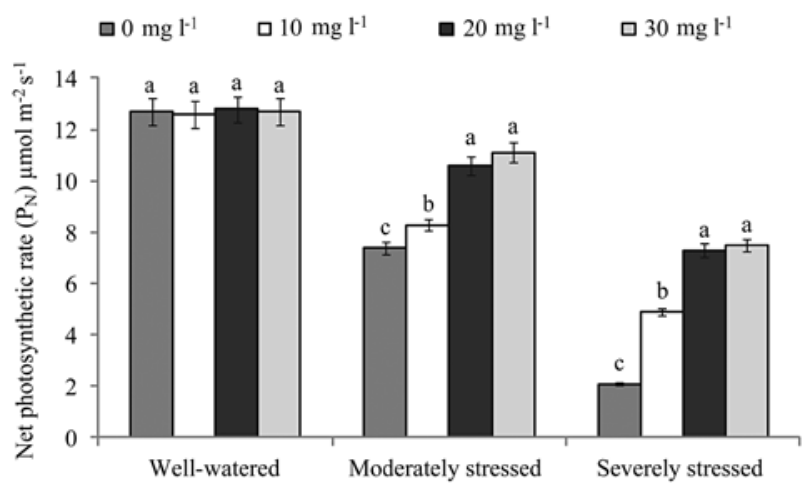

Note. Means not sharing a common letter $(\mathrm{a}, \mathrm{b})$ are significantly different $(P<0.05)$.

Figure 6. Effect of potassium bicarbonate $\left(\mathrm{KHCO}_{3}\right)$ on the net photosynthetic rate $\left(\mathrm{P}_{\mathrm{N}}\right)$ of green foxtail plants under different $(65 \pm 5 \%$ for well-watered, $45 \pm 5 \%$ for moderately stressed and $25 \pm 5 \%$ for severely stressed plants) substrate humidity

Stomatal and non-stomatal factors cause reduction in photosynthesis (Farooq et al., 2009). Decreased $g_{s}, E$ and $P_{N}$ in the present study indicated that reduction in photosynthesis of green foxtail under drought stress was caused by the stomatal factors. Under drought conditions, $\mathrm{K}$ concentration in plant cells decreases which can depress the plant resistance to drought stress (Wang et al., 2013). Stomatal closure and internal moisture retention are requisite for control plant water loss via transpiration during drought stress. It has been reported that potassium deficiency under drought increases the production of ethylene which could inhibit the action of abscisic acid on stomata, suspend stomatal closure and increase transpiration rate (Benlloch-Gonzalez et al., 2010). According to Farooq et al. (2009), drought induced stomatal closure resulted in parallel decline in net photosynthesis. In the present study, decreasing of net photosynthetic rate in $\mathrm{KHCO}_{3}$ treated plants under drought conditions was significantly lower in comparison with untreated plants. A significant increase in all gas exchange parameters in $\mathrm{KHCO}_{3}$ treated plants showed that $\mathrm{KHCO}_{3}$ may minimize photosynthetic losses under drought conditions and possibly could be useful for other $\mathrm{C}_{4}$ plants. Similar positive effect of potassium supply on $\mathrm{g}_{\mathrm{s}}, \mathrm{E}$ and $\mathrm{P}_{\mathrm{N}}$ was obtained for Hibiscus rosa-sinensis (Egilla et al., 2005) and Gossypium hirsutum (Pervez et al., 2004).

\section{Conclusions}

1. Drought conditions resulted in a significant increase in photoinhibition of photosystem II (PSII) in the plants of green foxtail. Decreased gas exchange parameters revealed that reduction in photosynthesis of green foxtail under drought stress was caused by stomatal factors.

2. Exogenous application of potassium bicarbonate $\left(\mathrm{KHCO}_{3}\right)$ increased the tolerance of green foxtail to the drought stress through increasing thermal dissipation of excess energy.

Received 07102016 Accepted 03012016

\section{References}

Benlloch-Gonzalez M., Romera J., Cristescu S., Harren F., Fournier J. M., Benlloch M. 2010. K+ starvation inhibits water-stress-induced stomatal closure via ethylene synthesis in sunflower plants. Journal of Experimental Botany, 61: 1139-1145 https://doi.org/10.1093/jxb/erp379

Brutnell T. P., Wang L., Swartwood K., Goldschmidt A., Jackson D., Zhu X. G., Kellogg E., Van Eck J. 2010. Setaria viridis: a model for $\mathrm{C}_{4}$ photosynthesis. The Plant Cell, 22 (8): 2537-2544

https://doi.org/10.1105/tpc.110.075309

Cakmak I. 2005. The role of potassium in alleviating detrimental effects of abiotic stresses in plant. Journal of Plant Nutrition and Soil Science, 168 (4): 521-530 https://doi.org/10.1002/jpln.200420485

Chaves M. M., Flexas J., Pinheiro C. 2009. Photosynthesis under drought and salt stress: regulation mechanisms from whole plant to cell. Annals of Botany, 103: 551-560 https://doi.org/10.1093/aob/mcn125

de Souza T. C., Magalhaes P. C., de Castro E. M., de Albuquerque P. E. P., Marabesi M. A. 2013. The influence of ABA on water relation, photosynthesis parameters, and chlorophyll fluorescence under drought conditions in two maize hybrids with contrasting drought resistance. Acta Physiologiae Plantarum, 35 (2): 515-527

https://doi.org/10.1007/s11738-012-1093-9 
Doust A. N., Kellogg E. A., Devos K. M., Bennetzen J. L. 2009. Foxtail millet: a sequence-driven grass model system. Plant Physiology, 149: 137-141 https://doi.org/10.1104/pp.108.129627

Earl H., Davis R. F. 2003. Effect of drought stress on leaf and whole canopy radiation use efficiency and yield of maize. Agronomy Journal, 95: 688-696 https://doi.org/10.2134/agronj2003.0688

Egilla J. N., Davies F. T., Boutton T. W. 2005. Drought stress influences leaf water content, photosynthesis, and wateruse efficiency of Hibiscus rosa-sinensis at three potassium concentrations. Photosynthetica, 43 (1): 135-140 https://doi.org/10.1007/s11099-005-5140-2

European Commission. 2014. Expert group for technical advice on organic production. Final report on plant protection products (II) <https://ec.europa.eu/agriculture/organic/ sites/orgfarming/files/docs/body/egtop-final-report-onppp-ii_en.pdf>

Farooq M., Wahid A., Kobayashi N., Fujita D., Basra S. M. A. 2009. Plant drought stress: effects, mechanisms and management. Agronomy for Sustainable Development, 29: $185-212$ https://doi.org/10.1051/agro:2008021

Foyer C. H., Noctor G. 2005. Oxidant and antioxidant signalling in plants: a re-evaluation of the concept of oxidative stress in a physiological context. Plant, Cell and Environment, 28: $1056-1071$ https://doi.org/10.1111/j.1365-3040.2005.01327.x

Ghannoum O. 2009. $\mathrm{C}_{4}$ photosynthesis and water stress. Annals of Botany, 103: 635-644 https://doi.org/10.1093/aob/men093

Genty B., Briantais J. M., Baker N. R. 1989. The relationship between the quantum yield of photosynthetic electron transport and quenching of chlorophyll fluorescence. Biochimica et Biophysica Acta, 990 (1): 87-92 https://doi.org/10.1016/S0304-4165(89)80016-9

Huang C., Zhao S., Wang L., Anjum S. A., Chen M., Zhou H., Zou C. 2013. Alteration in chlorophyll fluorescence, lipid peroxidation and antioxidant enzymes activities in hybrid ramie (Boehmeria nivea L.) under drought stress. Australian Journal of Crop Science, 7: 594-599

Layton D. J., Kellogg E. A. 2014. Morphological, phylogenetic, and ecological diversity of the new model species Setaria viridis (Poaceae: Paniceae) and its close relatives. American Journal of Botany, 101: 539-557 https://doi.org/10.3732/ajb.1300428

Li P., Brutnell T. P. 2011. Setaria viridis and Setaria italica, model genetic systems for the Panicoid grasses. Journal of Experimental Botany, 62 (9): 3031-3037 https://doi.org/10.1093/jxb/err096

Li Y. C., Hao J. J. 2013. The effect of $\mathrm{KHCO}_{3}$ on photosynthesis of eggplant seedlings. Advanced Materials Research, 634: 1129-1134 https://doi.org/10.4028/www.scientific. net/AMR.634-638.1129

Marku L., Vrapi H., Hasani M. 2014. Effect of potassium bicarbonate (Armicarb) on the control of apple scab (Venturia inequalis) in the region of Puka in Albania. International Refereed Journal of Engineering and Science, 3 (6): $25-30$

Nar H., Saglam A., Terzi R., Várkonyi Z., Kadioglu A. 2009. Leaf rolling and photosystem II efficiency in Ctenanthe setosa exposed to drought stress. Photosynthetica, 47: 429-436

https://doi.org/10.1007/s11099-009-0066-8
Oukarroum A., El Madidi S., Strasser R. J. 2012. Exogenous glycine betaine and proline play a protective role in heat-stressed barley leaves (Hordeum vulgare L.): a chlorophyll $a$ fluorescence study. Plant Biosystems, 146 (4): 1037-1043 https://doi.org/10.1080/11263504.2012.697493

Pervez H., Ashraf M., Makhdum M. I. 2004. Influence of potassium nutrition on gas exchange characteristics and water relations in cotton (Gossypium hirsutum L.). Photosynthetica, 42 (2): 251-255 https://doi.org/10.1023/B:PHOT.0000040597.62743.5b

Pinheiro C., Chaves M. M. 2011. Photosynthesis and drought: can we make metabolic connections from available data? Journal of Experimental Botany, 62 (3): 869-882 https://doi.org/10.1093/jxb/erq340

Reddy R. A., Chaitanya K. V., Vivekanandan M. 2004. Droughtinduced responses of photosynthesis and antioxidant metabolism in higher plants. Journal of Plant Physiology, 161: 1189-1202 https://doi.org/10.1016/j.jplph.2004.01.013

Saglam A., Kadioglu A., Demiralay M., Terzi R. 2014. Leaf rolling reduces photosynthetic loss in maize under severe drought. Acta Botanica Croatica, 73 (2): 315-332 https://doi.org/10.2478/botcro-2014-0012

Tarakanovas P., Raudonius S. 2003. Agronominių tyrimų duomenu statistinè analizè taikant kompiuterines programas ANOVA, STAT, SPLIT-PLOT iš paketo SELEKCIJA ir IRRISTAT. Lithuanian University of Agriculture, 58 p. (in Lithuanian)

Wang M., Zheng Q., Shen Q., Guo S. 2013. The critical role of potassium in plant stress response. International Journal of Molecular Sciences, 14: 7370-7390 https://doi.org/10.3390/ijms14047370

Wenneker M., Kanne J. 2010. Use of potassium bicarbonate (Armicarb) on the control of powdery mildew (Sphaerotheca mors-uvae) of gooseberry (Ribes uvacrispa). Communication in Agricultural and Applied Biological Sciences, 75 (4): 563-568

Yao L., Yu Y., Hao J. J. 2009. Effects of $\mathrm{KHCO}_{3}$ on photosynthetic rate and growth of rice seedlings. Journal of Shenyang Agricultural University, 40 (6): 720-722 
ISSN 1392-3196 / e-ISSN 2335-8947

Zemdirbyste-Agriculture, vol. 104, No. 1 (2017), p. 79-84

DOI $10.13080 / \mathrm{z}-\mathrm{a} .2017 .104 .011$

\section{Kalio hidrokarbonato poveikis Setaria viridis fotosintezès parametrams sausros sąlygomis}

N. Burbulis, R. Vainorienè, A. Blinstrubienè, V. Jonytienè, V. Liakas

Aleksandro Stulginskio universitetas

\section{Santrauka}

Tirtas sausros streso ir kalio hidrokarbonato $\left(\mathrm{KHCO}_{3}\right)$ poveikis žaliosios šerytės (Setaria viridis (L.) Beauv.) II fotosistemai (PSII) vidutinès ir stiprios sausros sąlygomis. Augalai, esantys 13 fenologinėje fazeje (pagal BBCH skalę), buvo suskirstyti ị tris grupes ir nupurkšti vandeniu arba 10, 20 ir $30 \mathrm{mg}^{-1}$ koncentracijų $\mathrm{KHCO}_{3}$ tirpalais. Pirmosios grupès augalai (ịprastos drègmès sąlygos) buvo laistomi kas antrą dieną. Antrosios (vidutinès sausros sąlygos) ir trečiosios (stiprios sausros sąlygos) grupių augalai buvo nelaistomi sudarant sausros sąlygas. Nustatyta, kad sausros sąlygos mažino maksimalų ir efektyvų kvantų našumus, veikiausiai dèl II fotosistemos slopinimo. Sumažèję dujų apytakos parametrai parodo, kad žaliosios šerytès fotosintezès intensyvumo sumažėjimas sausros sąlygomis nulemiamas žiotelių laidumo. Reikšmingas maksimalaus ir efektyvaus kvantų našumų ir dujų apytakos parametrų padidejjimas paveikus $\mathrm{KHCO}_{3}$ ịrodo, kad kalio hidrokarbonatas apsaugo žaliosios šerytès augalų II fotosistemą nuo sausros pažeidimų ir gali būti veiksmingas kitiems $\mathrm{C}_{4}$ fotosintezès tipo augalams.

Reikšminiai žodžiai: II fotosistema, $\mathrm{KHCO}_{3}$, sausros stresas, žalioji šerytė. 